\title{
On Manolin's Symbolic Meaning in the Old Man and the Sea
}

\author{
Hong-xia $\mathrm{LI}^{1}$ and Xiao-bing $\mathrm{QI}^{2,{ }^{*}}$ \\ ${ }^{1}$ School of Humanities of YiLi Normal University, Yining, Xinjiang 835000, China \\ ${ }^{2}$ School of Humanities of YiLi Normal University, Yining, Xinjiang 835000, China
}

Keywords: Manolin, Love, Loyalty, Spiritual continuation.

\begin{abstract}
There are many researches about the old man and the sea in China and abroad, such as "The tough guy" "Heroism" "Iceberg theory". However, there are little comments about the little boy. It seems that his role is irrelevant and unimportant to the novella. In fact, it is worthwhile for us to learn his spirit and quality. Using text-analysis mainly explores Manolin's symbolic meaning to prove his importance to this work. The symbol of love, loyalty and spiritual continuation in the little boy highlight the old man from all aspects, Spread the infinite positive energy between the lines and enrich the meanings of literary works in details. Therefore, the little boy is an indispensable and significant role to be considered and explored.
\end{abstract}

\section{Introduction}

In the 1930s, Ernest Hemingway went to Key West, Florida, and later lived in Cuba. This experience of fishing in the Gulf Stream and the Caribbean provides indispensable background materials for the work the Old Man and the Sea. Thanks to this experience, many vivid descriptions of the fisherman's craft can be made. In 1952, the Old Man and the Sea was published, and it won great success. The Old Man and the Sea made Hemingway win the Pulitzer Prize for fiction in 1953, and win the Nobel Prize for literature in 1954. Therefore, his writing career went to the peak. However, every critic has his opinion. "While some critics have praised the Old Man and the Sea as a new classic that takes place among such established American works as William Faulkner's short story "The Bear" and Melville's Moby-Dick, others have attacked the story as "imitation Hemingway" and find fault with the author's departure from the uncompromising realism with which he made his name." (Zhang, 2003:3, 5) It's a pity that the Old Man and the Sea was the last novel in his life time.

No doubt that there are so many researches on the Old Man and the Sea. Some researches talk about "the tough guy"; some focus on "heroism"; some concentrate on "iceberg theory"; some explore "crucifixion imagery". But the research about Manolin needs to be made. Although Manolin is a secondary role, the overlook of him will have an influence on our understanding and review for the novella. This role of Manolin's description is rare in the novella, but he appears in the key development of the plot. From the structure of the novella, Manolin has presented at the beginning; when Santiago goes out to the sea by himself he comes up in the old man's mind again; when the old man comes back from the sea, Manolin comes to comfort and accompany him. From the social relationship, the little boy is the old man's apprentice, they know each other very well, and get along with each other very well. The old man has no children, and his wife died early, only the little boy takes care of him. From the thing of Santiago's going out to sea, Manolin plays an important part. Although there is not any description about this character's appearance, his age and his family background information, nobody can take place of him in the novella. Through exploring Manolin's symbolic meaning with text-analysis proves his importance to this work. The symbol of 
love, loyalty, and the spiritual continuation demonstrate that the little boy is an indispensable role in the Old Man and the Sea. The little boy's positive attitude toward life and kindness and generosity benefit us around the world.

\section{The Symbol of Love in Manolin}

\section{Helping to Embody the Old Man's Pressure}

"Grace under pressure" can embody "tough guy" fully and perfectly in the Old Man and the Sea. In order to show the old man's pressure in that situation well, Hemingway makes the most use of the little boy's love. In the text, at the very beginning of the novella, when the little boy leaves the old man because his parents force him to do so, the pressure on the old man is increased.

From the beginning of the novella, everybody knows that the old man, an aged Cuban fisherman, for eighty-four days, has set out to sea and returned empty-handed. There is no doubt that Santiago at this moment is confronted with the big challenge. However, only through a number " 84 days" and the situation of poverty cannot be enough to arouse readers' sympathy. Moreover, the expressions and descriptions later discussed are difficult to impress the readers and the novella's width and depth cannot be deepened. At the same time, it is difficult to make readers come across through words and the old man's dilemma in the novella. Therefore, Hemingway deliberately describes the little boy considerably in order to highlight a gradual deteriorated situation of the old man.

\section{Showing the Old Man's Grace}

Firstly, the refusal to the little boy's return shows that he is positive, optimistic, and confident towards life. When he has been unable to catch a fish for eighty-four days, and the only companion, and friend is forced to leave him, he could not show any frustration and depression and instead he is "cheerful and undefeated"(Ernest Hemingway,2005:2). When the little boy asked to go with him again, he said "no, you are with a lucky boat. Stay with them." (Ernest Hemingway,2005:4)Because the boy's parents made this decision, he would not make the boy embarrassed and upset, and would not let the boy become unlucky with him again. It is no doubt that the old man has a kind of good sense of responsibility. "His confidence and his hope had never gone. But now they were freshening as when the breeze rises" (Ibid). The old man always entertains a sort of positive life attitude.

Secondly, the gentle action of waking Manolin embodies his tender feelings. "He took hold of one foot gently and held it until the boy woke and turned and looked at him." (Ernest Hemingway, 2005:12) As we know that the old man is a typical "Hemingway's tough guy", but it cannot say that he doesn't have human kindness, instead it just sates his grace in the balance of hardness and softness.

Thirdly, the braveness and tenacity in his fight with fish shows Santiago's grace undoubtedly. During the course of fighting with the fish, Santiago always endures the pain from the fishing line. When the fish wants to jump, leap, or make a dash for freedom, the rope of fishing cuts him badly and injured him seriously. Although the old man has been exhausted and wounded, the old man feels sympathetic toward the marlin so that he looks it as his brother in suffering, strength, and resolve. Finally, the old man manages to pull the marlin out closely and kills it successfully with a harpoon. As he continues to sail on with fish, the blood of marlin attracts sharks. In order to protect his marlin, the old man has to fight off the sharks over and over. "The old man fights off the shark with the spear he makes by lashing a knife to an oar, and even clubbing them with 
the boat's tiller" (Zhang,2003:9). Santiago kills sharks, but so many sharks appear again, at last he gives up. Marlin leaves only skeleton, head, and tail. The little boy has been worried about the old man, when he is fighting with the fish on the sea for three days. Manolin cried four times when he finds the old man safe on the bed.

\section{Sublimating the The me of the Novel}

The descriptions of the relationship between the old man and the little boy make the content of the work richer, and make the theme of the work expanded. Meanwhile, the beginning and the ending of descriptions of Manolin's love and respect for Santiago strongly demonstrate that Santiago is extraordinary. The relationship of between Manolin and Santiago is a kind of "metaphor" as the relationship between Saints and Jesus. Santiago took up the mast and started to climb, which makes others associate with the scene of Jesus's going to eternity on the cross; On the sea, the old man fight with the marlin and let out cry "Ay" when he was injured, at this time, writer said that this word "Ay" cannot be translated vividly, and it is maybe like a sound of crying from a person who felt that nails penetrating his palms into wood, and could not help shouting. This is a kind of "suggestion", which naturally makes people associate with two hands of Jesus nailed on the cross. Moreover, the little boy is the symbol of love in life, and he uses his simple love to play a song of love. Because the failure of Across the River and into the Trees, Hemingway attempt to avoid his miserable loneliness and frustration in his life in the work, but it is filled with light loneliness and depression, which makes people feel like a masterpiece of life. But we think that the love of Manolin for the old man melts the loneliness of the old man, comforting the soul of the old man, meanwhile warming the hearts of the readers. Nonetheless, Manolin's love for the old man makes us impressed and moved.

\section{The Symbol of Loyalty in Manolin}

\section{Highlighting the Old Man's Charming}

After getting through forty days' nothing, the little boy is forced to leave the old man. Four days later, this is the first time for Manolin to ask to sail with the old man again. Although the old man refuses him, it is enough to show the charm of Santiago for Manolin.

When the old man has experienced about three months' getting nothing, for Santiago, he is extremely eager for company of Manolin actually. Even if Manolin sails in other boat, he is still concerned about the old man, and keeps loyalty for the old man. He still looks after, cares about, and loves the old man. Manolin is his apprentice and devoted attendant. The old man first took the little boy to go out the sea on the boat when he was very young. "The old man had taught the boy to fish and the boy loved him." (Ernest Hemingway, 2005:2) As we know, when we have a lot of money, we can share a little with the poor. When a millionaire donates one dollar or more, but we know he is never willing to give out total properties. Nevertheless, the little boy is much pleasured to give what he has to the old man. For example, he caught three good fish in another boat after leaving the old man's boat, and he made some money. He is willing to share his money with the old man without any hesitation. From my point of view, others especially the little child never did it. This could mean that the old man is so charming and the little boy is very loyal to him. He once said to him: "There are many good fishermen and some great ones. But there is only you."(Ernest Hemingway, 2005:10) The old man's noble quality and super fishing techniques win his love and 
respect. He leaves the old man but doesn't abandon him, and still cares for the old man as always.

\section{Elevating the Old Man's Defeat}

For Santiago, the destruction of marlin is a great loss, but it is not a defeat. On the contrary, the destruction of fish makes him transcend the failure of the surface. He gets the great respect from the fishermen who made fun of him. Most importantly, he makes the little boy come back. Manolin's meticulous care and attention to the old man, and great fidelity make him become the symbol of love and loyalty.

From the very first paragraph, Santiago is characterized as someone struggling against defeat. He has gone eighty-four days without catching a fish, and he will soon pass his own record of eighty-seven days. So he decided to change his luck and sail out farther than he or other fishermen ever have before. Later he met with the Marlin, he displays both pity for the fish and an unflagging determination to kill it. The ending of death of the marlin on the fourth day marks the climax of the Old man and the Sea. Marlin makes his last fight, and exhibits to Santiago "all his power and his beauty" (Ernest Hemingway, 2005:52). During his way back to the village, he suffered the attack from sharks. "He hit the shark without hope but with resolution and complete malignancy" (Ernest Hemingway, 2005:57). The old man meets every challenge with the same unwavering determination. At last, the old man cannot bring his trophy of his long battle, and the marlin was eaten up but the skeleton. Due to his age, he will never have the opportunity to catch such a magnificent fish again. It seems that Santiago was defeated thoroughly. Nevertheless, after he returns to the village, his spirit, his value and reputation revitalize. The little boy's return and loyalty embody the old man has won. The old man is the winner of his lives. Therefore, the little boy's loyalty ele vates the old man's defeat.

\section{Demonstrating the Old Man's Value}

At the beginning, the old man is the laughingstock of the villagers without catching a fish. He is very poor and often has no food. Even if the little boy doesn't sail with him, he still helps him do something: tidying fishing gear, providing food, and discussing American baseball's latest developments. On one hand, the little boy behaves like this because he thanks the old man and loves him. On the other hand, the real reason is the old man's value. In other words, there are so many things to learn from him including fishing techniques and the spirits of persistence.

Manolin sets his mind to reunite with the old man regardless of his parents' disturbance which not only shows his loyalty but also demonstrates the fisherman's value. Santiago is an expert seaman, earning Manolin's praise and dedication. The old man can be able to read the sea, sky, and their respective creatures, and can tell Manolin everything he wants to know like an cyclopedia. Santiago suffers so much and faces so many troubles in the Old Man and the Sea. He suffers the mockery of other fisherman when he has gone eighty-four days without catching a fish. He then endures a long and grueling struggle with the marlin with the result of his trophy destroyed by sharks. Santiago's resolve, unflagging determination, and strength in face of tremendous obstacles, can prove that he is a tough guy and a hero. His value as a man and a fisherman can be showed fully. 


\section{The Spiritual Continuation in Manolin}

\section{Representing the Continuation of Old Man's Life}

"Death is the unavoidable force in the novella, the one fact that no living creature can escape. But death, Hemingway suggests, is never an end in itself: in death there is always the possibility of the vigorous life. The reader notes that as Santiago slays the Marlin, not only is old man reinvigorated by the battle, but the fish also comes alive 'with his death in him.' Life, the possibility of renewal, necessary follows on the heels of death."'(Zhang, 2003:33) At the ending, Hemingway employs a number of ima ges that links Santiago to Christ. In the novella, there are three scenes portrayed as a crucified martyr: the first one is that as soon as the sharks arrive, Santiago made the noise like that one would make "feeling the nail go through his hands and into the wood."(Ernest Hemingway,2005:59); The second one is the descriptions of Santiago's return to town also recalls the crucifixion; The third one is that as the old man struggles up the hill with his mast across his shoulders, readers cannot help recalling Christ's march toward Calgary. Jesus is a model of transcendence, turning loss into gain, defeat into triumph, and death into new life.

All of these scenes suggest that the old man's life will continue on after his death through his devotee Manolin. All of the old man's noble qualities and the lessons he draws from his experience, will be passed on to Manolin, which means the old man's life will continue on in Manolin's form after his death.

\section{Representing the Continuation of Old Man's Spirits}

As we know, man cannot live all the time. One day, the old man will pass away, but his spirits will continue through Manolin, as the old man's only apprentice. Manolin's actions have no mix with confusion and ambivalence. He is a devoted companion and a kind partner. The old man's spirits won't be lost.

Moreover, the ending of the novella of the little boy's return also indicates that Manolin will be his spirits' successor of unflagging determination to catch the Marlin. When it comes to the old man's spirits, Joe DiMaggio must be mentioned. Although Joe DiMaggio never appears in the novel, he plays a significant role nonetheless. Santiago regards him as a model of strength and commitment, a mode of wisdom and persistence. DiMaggio's pain of his bone is hard to bear, if replacing of another player, he might have become a cripple. But DiMaggio goes on to make some achievements. DiMaggio was regarded as the best player as a center fielder. He worked on the New York Yankees from 1936 to 1951 at that time. When Santiago feels lack of confidence, he will think of him. From the description of DiMaggio, we can realize the old man's persis tence, courage, resolve, strength.

In conclusion, readers will be delighted for the old man who has a qualified successor. As the old man's only apprentice, the little boy also represents the old man's life that will continue after Santiago's death. His dedication to learning from the old man ensures that Santiago's spirits will live on.

\section{Ensuring to Move and Inspire Readers}

In the novella, mandolin, the second important role, plays the part of moving and inspiring the readers. Although the little boy only presents at the beginning and the ending of the novella, and there aren't so many descriptions and expressions about the little boy, his every act and every move affect readers' hearts.

At the beginning, the author tells us that Santiago has had an extended run of bad luck. He couldn't catch a fish for eighty-four days. The first forty days, a little boy 
comes with him, but because they cannot catch a fish, their parents force the little boy to leave Santiago and catches fish in another boat. The first week they catch three big fish, whereas Santiago didn't catch a fish for eighty-four days. This unlucky condition makes us extremely sad. But at this time when Santiago most needs others to comfort, the devoted Manolin leaves him. This will make the old man's fate much more miserable, which arouses readers' great sympathy and sentiments.

At the ending, the author makes a detailed description of Manolin's weep, which builds a dense tragic atmosphere effectively. The first weep is because Manolin saw the old man's wounded hands; the second weep is when he brings some coffee, and all the way he was crying; the third weep is when other fisherman asks how the old man is, "he did not care that they saw him crying."(Ernest Hemingway, 2005:68) The fourth weep is when the proprietor said that he took two fine fish yesterday, maybe he felt regretful not to stay with the old man. The fifth weep is when he brings stuff from the drug store for Santiago's hands, "as the boy went out the door and down the worn coral rock road he was crying again."(Ernest Hemingway, 2005:70) Manolin's cry is his complex feeling's spreading naturally. When readers appreciate the little boy's "cry", they will be touched naturally for Manolin's sorrowful emotion and feel sympathetic for Santiago's misfortune.

\section{Conclusion}

Manolin, as a minor character, is an indispensable and significant role to be considered and explored in the Old Man and the Sea. The existence of Manolin not only shows the charm of the old man, but also moves and inspires readers. We can never ignore him, although Manolin only presents at the beginning and the ending of the novella. The importance of the little boy cannot be overlooked. The character of the little boy leaves a good impression in readers' mind from the beginning to the end. It is acknowledged that Hemingway relies on the boy to sublimate the old man's image of "tough guy" and win the readers' love and sympathy for Santiago. Therefore, when we read a literary work, we'd better think over every character the writer shaped in the work. We also might well think over valuable life lessons given in the work. The attitude toward life and the kindness and generosity in the boy benefit everybody on the way of life.

\section{References}

[1] Ernest Hemingway. The Old Man and the Sea, Shanghai: Shanghai Foreign Language Education press, 2005.

[2] Ernest Hemingway. The Old Man and the Sea, Trans. Guojing Zhang. Tianjin: Tianjin science and technology translation publishing company, 2003.In Chinese.

[3] Yaoxin Chang. A Survey of American Literature, Tianjin: Nankai University Press, 1990.

[4] Baker, Carlos. Ernest Hemingway: A Life Story, New York: Charles Scribner's Sons, 1969.

[5] Baker, Carlos. Hemingway: The Writer as Artist, Princeton, New Jersey: Princeton University Press, 1972. 